NBER WORKING PAPER SERIES

FIRM DIVERSIFICATION AND

CEO COMPENSATION: MANAGERIAL

ABILITY OR EXECUTTVE

ENTRENCHMENT?

Nancy L. Rose

Andrea Shepard

Working Paper No. 4723

NATIONAL BUREAU OF ECONOMIC RESEARCH

1050 Massachusetts Avenue

Cambridge, MA 02138

April 1994

We are grateful to the National Science Foundation, the MIT Center for Energy and Environmental Policy Research, and the Alfred P. Sloan Foundation for financial support of this project. This research was undertaken while Rose was a fellow at the Center for Advanced Study in the Behavioral Sciences. We thank Severin Borenstein, Ben Hermalin, Paul Joskow, Richard Lambert, Edward Lazear, James Poterba, Garth Saloner and Mark Wolfson, and participants in the Stanford Brown Bag Lunch and the NBER Industrial Organization program for helpful discussions, and Justin Adams for data assistance. This paper is part of NBER's research program in Industrial Organization. Any opinions expressed are those of the authors and not those of the National Bureau of Economic Research. 


\title{
FIRM DIVERSIFICATION AND \\ CEO COMPENSATION: MANAGERIAL ABILTY OR EXECUTIVE \\ ENTRENCHMENT?
}

\begin{abstract}
Data for a sample of 558 CEOs over 1985-1990 suggest substantial compensation premia for managers of diversified firms. The CEO of a firm with two distinct lines of business averages 10 to 12 percent more in salary and bonus and 13 to 17 percent more in total compensation than the CEO of a similar-sized but undiversified firm, all else equal. This corresponds to average 1990 salary gains of $\$ 115,000$ to $\$ 145,000$ per year for our sample. Diversification may raise pay because the CEO's job requires higher ability or because it is associated with CEO entrenchment. If ability explains the correlation, we would expect the diversification premium to be invariant to tenure. Entrenchment models suggest higher premia for more experienced (more entrenched) CEOs, and an increase in compensation when the CEO diversifies the firm. The data support an ability model over an entrenchment explanation. The diversification premium is unaffected by tenure, and increasing diversification reduces compensation for incumbent CEOs, all else equal.
\end{abstract}

Nancy L. Rose

MIT Sloan School

50 Memorial Drive, E52-434

Cambridge, MA 02142

and NBER

\author{
Andrea Shepard \\ Stanford GSB \\ Stanford University \\ Stanford, CA 94305 \\ and NBER
}




\section{INTRODUCTION}

The economics and strategic management literatures of the past decade have grown increasingly skeptical about the value of combining several lines of business within a single firm. The positive literature has noted the negative response of the stock markets to diversifying mergers in the 1980s (e.g., Morck, Shleifer and Vishny, 1990) and the relatively poor performance of diversified firms (e.g., Lang and Stulz, 1993). The normative literature has shifted from an enthusiasm for portfolio management within diversified firms in the 1970s to a more tempered discussion of how corporate managers might make the diversified whole more valuable than the sum of its parts (e.g., Porter, 1985).

The effort to understand why diversification failed to produce the performance gains anticipated during the 1960 s conglomerate merger wave has produced two sharply divergent classes of explanations. One focuses on the difficulty of managing diversified enterprises, the other on managerial entrenchment. Both imply a connection between CEO compensation and firm diversification. This study uses information on 558 CEOs in 418 firms over 1985-1990 to explore this connection. We find evidence of significant compensation premia for managers of diversified enterprises. We use patterns in these premia to distinguish entrenchment explanations from those based on managerial ability.

Ability-based explanations focus on the difficulty of managing a diversified firm. Diversification is undertaken if it increases the expected value of the firm through some type of synergy or spillover across the lines of business. Realizing the potential value of these synergies depends on the ability of top management. If diversification increases the value the firm places on managerial talent, more diversified firms will hire more able CEOs. Because 
ability earns a premium in the market for corporate talent, CEOs at diversified firms will be more highly compensated than are their counterparts at less diversified firms. Ability models imply that the diversification premium will be invariant to CEO tenure, and that incumbent CEOs who diversify their firms will be paid less than CEOs who are optimally matched to the firm's new, higher level of diversification.

Proponents of managerial entrenchment explanations argue that diversification frequently is undertaken by self-serving managers to increase the value of their compensation packages, even when diversification reduces the value of the firm. One simple story is that diversification is an easy way to increase firm size when antitrust constraints restrict acquisitions within a firm's existing lines of business. If Boards of Directors reward CEOs for firm size, CEOs may have an incentive to diversify even when it does not contribute to shareholder wealth. A more subtle argument, and the one on which we focus here, is that top executives change the scope of the firm to match their particular talents. If diversification creates a uniquely good match between top executives and the firm, it creates managerial rents that may be captured by the CEO (Shleifer and Vishny, 1989). These models predict compensation increases for incumbent CEOs who diversify their firms, a positive correlation between compensation and diversification in the cross-section, and smaller diversification premia for new CEOs than for incumbent CEOs.

Both entrenchment and ability explanations imply a positive cross-sectional correlation between compensation and firm diversification, holding constant firm scale and other variables known to affect compensation. This is confirmed in our sample of 480 "experienced" CEOs- those who have been in the position for more than two years. These results, which are dominated by interfirm variation, suggest economically and statistically 
significant diversification premia in CEO compensation. Firms with two distinct lines of business pay, on average, 10 to 12 percent more in salary and bonus and 13 to 18 percent more in total compensation than do similar but undiversified firms. Compensation increases further, but in smaller increments, with diversification into additional business segments.

The power to distinguish between ability and entrenchment explanations comes from examining diversification premia for new CEOs and from estimating first-difference specifications to isolate the response of compensation to changes in diversification initiated by incumbent CEOs. We find that the diversification premium for our sample of 172 first-year CEOs is roughly equal to that earned by the panel of experienced CEOs. The first-difference results suggest that increasing diversification fails to increase compensation. Indeed, the data suggest a premium for reducing diversification, all else equal. These patterns provide strong support for ability-based explanations over managerial entrenchment explanations of diversification premia.

The paper is organized as follows: In section II, we discuss the two competing explanations of the connection between CEO compensation and firm diversification. The data and empirical specification used to test these views are described in section III. Results are presented in section IV, followed by a brief conclusion.

\section{DIVERSIFICATION AND EXECUTIVE COMPENSATION}

There are two general views of the relationship between diversification and compensation. The first is predicated on a belief that market mechanisms effectively align the interests of the CEO with those of the firm's stakeholders. Given this, compensation will reflect the CEO's contribution to the value of the firm. If diversification affects compensation, it is 
because diversification changes the value of managerial input. We refer to models taking this general perspective as managerial input or "ability" models. The opposing view is that CEOs have considerable latitude to pursue their own objectives at the expense of shareholders' interests. These objectives may include diversification if it enables CEOs to increase their compensation, or if CEOs have a taste for diversification itself. We refer to models based on this view as "entrenchment" models. We discuss below the implications of these competing explanations for the relationship between executive compensation and firm diversification.

\section{Diversification and CEO Ability}

A common justification for diversification is potential synergies or spillovers across lines of business. Broadly interpreted, these include spillovers from R\&D activities, synergies from capabilities applicable to multiple lines of business, economies of scope from slack resource constraints or amelioration of market power in upstream or downstream markets through vertical integration. These potential gains may be offset by an increased load on limited managerial inputs. In particular, the demand for managerial input at the CEO level is likely to increase with firm diversification. Diversification may increase the complexity of the CEO's job (Finkelstein and Hambrick, 1989); at a minimum, it increases the complexity of the resource allocation decision. Operating in more than one industry requires the CEO to understand several, potentially quite disparate, product markets. A CEO of a firm in multiple lines of business must evaluate competitive strategies for product lines that may have different customers, different industry structures, and different competitors. Managing diverse lines of business may require deploying a broad variety of resources and capabilities. Finally, realizing potential synergies involves facilitating coordination and communication across business groups within the firm. 
All these factors suggest that the firm's marginal return to executive talent will increase with diversification.

In an efficient market for managerial talent, this higher return will lead to higher compensation at more diversified firms. Equilibrium effects of diversification on compensation can be illustrated in a simple matching model, where managers with higher ability are matched with positions in which the marginal return to ability is higher (Rosen 1982, Waldman 1984). In these models, managers contribute to the productivity of all workers below them in the firm's hierarchy, and more able managers make a larger contribution than less able managers. The marginal return to ability realized by the firm is the increment to productivity caused by hiring a person of higher ability in a given position and is a characteristic of the firm. Characteristics that increase the marginal return to ability in the position will have two equilibrium effects: the ability of those selected to fill the position will be greater, and the compensation associated with the position will be higher.

This argument implies a positive correlation, ceteris paribus, between firm diversification and CEO compensation, and a positive coefficient on a diversification index in cross-sectional compensation regressions. Since the ability of the CEO in these models is not a function of tenure, the predicted diversification premia are the same for new and experienced CEOs.'

Matching models provide little guidance on the expected impact of changes in diversification on the compensation of incumbent CEOs. If CEO

'Compensation empirically tends to increase slightly with tenure in the position, which may reflect human capital accumulation. Unless the ability to manage a diversified firm increases differentially with tenure, this should not affect the diversification premium. 
replacement were costless, these models imply that changes in diversification should lead the firm to replace the current CEO with one whose ability optimally matches the firm's new scope. Because CEO turnover is costly to both the firm and the CEO, there is value to retaining the incumbent CEO as long as the mis-match is not too severe. This suggests that changes in diversification may lead to bargaining between the CEO and the firm, with both parties sharing the costs of the mis-match. As a result, the compensation of incumbent CEOs who have increased their firm's diversification should be less than the compensation that would be earned by a new, optimally-matched CEO. Similarly, the compensation earned by incumbents who have reduced their firm's compensation should be higher than that of the less able, but optimally matched CEO. This suggests that the correlation between changes in diversification and changes in compensation for incumbent CEOs will be smaller than the correlation between compensation and diversification observed in the levels regressions.

\section{Diversification and Management Entrenchment}

An alternative explanation for the relation between firm diversification and CEO compensation is managerial entrenchment. A growing academic literature as well as popular press accounts of top management in large public corporations focuses on possible misalignments between shareholders' interests and the CEO's objectives. The primary mechanisms for aligning incentives - pay-for-performance, monitoring by shareholders or their representatives, and the market for corporate control - might not be sufficiently powerful or precise to prevent self-serving decisions that are good for managers but not for owners. Executive compensation schemes, it is argued, provide insufficient performance incentives to make shareholder wealth maximization the top executive priority (e.g., Jensen and Murphy, 1990). Boards of Directors may have inadequate information and incentives 
to monitor and control CEO behavior (Mace, 1971). The market for corporate control, which may discipline particularly egregious mismanagement, is at best an imperfect mechanism given the transactions costs incurred in its use.

Absent effective controls on executive behavior, CEOs may pursue a variety of objectives (including, perhaps, increased diversification), regardless of whether they are consistent with shareholders' objectives. If CEOs can enforce self-serving decisions, there are a variety of channels through which diversification and compensation might be linked. Some of these are indirect: diversification may change the firm's size or risk profile, both of which directly affect compensation. These explanations suggest no direct influence of diversification on compensation in the presence of controls for scale and risk. There are, however, two entrenchment arguments that imply a relationship between diversification and compensation even when size and risk are held constant.

The first is a variant on the ability matching model in which the CEO creates a good match by diversifying the firm. Shleifer and Vishny (1989) argue that CEOs may use diversification to increase their value to the firm if diversification enables the CEO to create an industry mix for which his/her managerial skills are uniquely well-suited. By increasing the value to the firm of his/her specific human capital, the CEO is able to negotiate a higher wage with the Board of Directors. ${ }^{2}$ Incumbent CEOs who diversify their

\footnotetext{
2The compensation increase will depend on the difference between the value to the firm of the incumbent CEO and the value of the next best qualified manager. This can be thought of as the rent value of the incumbent CEO's unique talents. Note that this argument implicitly assumes that the CEO cannot seek employment with a firm already active in the areas to which she/he is uniquely well-suited and that it is easier for the CEO to affect the scope of the firm than the level of CEO compensation.
} 
firms should be rewarded with higher compensation if this is the dominant source of a diversification-compensation link. ${ }^{3}$ This will tend to generate positive correlations between diversification and compensation for experienced CEOs (those who could have diversified their firms) in the levels equations. Compensation premia should be much smaller for new CEOs, who by assumption are discretely less well-qualified to manage the firm than are the CEOs who created the diversification. In a first difference specification, changes in diversification and compensation should be correlated.

A second argument for a linkage between compensation and diversification is that managers have a taste for both more diversification and higher compensation." CEOs who are more powerful vis-a-vis their Boards are better able to implement their preferences, leading to both greater diversification and higher compensation at these firms. This implies a positive cross-sectional correlation between pay and diversification, and a positive correlation between changes in diversification and changes in compensation, both caused by unobserved variations in CEO entrenchment. Entrenchment is likely to increase with tenure because the CEO has more opportunity to influence the composition of the Board of Directors and to

II the rent value of a CEO's human capital were maximized by specializing the firm, this model suggests that entrenched managers would reduce diversification. In this case, compensation would be negatively correlated with diversification in both cross-sections and firstdifferences.

- The compensation preference seems clear. CEOs may like diversification because it is a relatively easy way to affect the direction of the firm. GE's 1976 acquisition of a billion dollar mining company, for example, was attributed by the business press to a desire by the CEO to make a "lasting imprint on his firm" (Fortune, August 1977). Roll (1986) argues that acquisition decisions in general may be the result of CEO "hubris", a belief that they are uniquely well qualified to evaluate and/or manage the target firm. 
build a constituency among managers within the firm. This suggests that new CEOs should average smaller estimated diversification premia than those of experienced CEOs. ${ }^{5}$

\section{AN EMPIRICAL MODEL OF COMPENSATION}

We explore the effects of diversification on CEO compensation by embedding a measure of diversification in a standard empirical model of executive compensation (see Joskow, Rose, and Shepard, 1993). Compensation is a function of firm characteristics such as size, financial performance, and the extent of diversification; CEO characteristics such as age and tenure; and industry norms and economy-wide shifts in managerial compensation, captured by industry and year fixed effects. The data and specification of the compensation equation are described below.

\section{Data}

This study combines information on CEO compensation and characteristics from Forbes' annual CEO compensation survey with information on firm characteristics from Standard and Poor's Annual and Industry Segment COMPUSTAT files and the Center for Research on Security Prices (CRSP) returns files. We delete firms in financial services or regulated industries, leaving 1830 CEO-years over 1985-90 that match across our four data sources. "The analysis of "experienced" CEOs is restricted to those with

${ }^{5}$ Sample selection biases also may induce a positive correlation between tenure and unobserved entrenchment: as, for example, if more entrenched managers are able to stay in the CEO position longer than the average CEO.

- Firm deletion is based on their primary industry assignment, as recorded by COMPUSTAT. Regulated industries during our sample period include electric or gas utilities, gas pipelines, and telephone service. Regulated and financial services industries are omitted due to noncomparability in firm data and differences in the structure and level of 
more than two years of tenure in the CEO position. This yields a panel data set of 1505 observations on 480 CEOs in 403 firms. Our analysis of new CEOs is based on 172 CEOs whom we observe in their first year of office. Table 1 reports summary statistics for the experienced CEO panel in columns 1 through 3; summary statistics for the first-year sample are reported in column 4. Variable descriptions follow below.

Compensation Measures. We use two measures of CEO compensation. The first is salary and bonus (SALARY), whether current or deferred. This component of compensation is relatively well-defined and consistently measured across firms and over time for our sample period. The second, total compensation (TOTAL), is the most inclusive measure of compensation reported by Forbes. It includes benefits, long-term and contingent compensation, and net gains from the exercise of stock options, stock appreciation rights and stock accrual rights (collectively referred to below as "options"). TOTAL mismeasures current compensation for two reasons. First, it understates current compensation in years that CEOs receive substantial options grants; the ex ante value of options is not recorded as compensation. Second, it overstates current compensation in years that options are exercised, when the entire ex post gain is attributed to current compensation. It is, however, the best measure of total compensation in our data set. ${ }^{7}$

compensation across these and the remaining industries in our sample (Joskow, Rose, and Shepard, 1993). The short sample period is due to the restricted span (7 years maximum) of COMPUSTAT's Industry Segment File.

7 Forbes does not provide sutficient information on options awards to support a more sophisticated treatment, even if one could solve the valuation problem for unexercised options. 
The mean real SALARY in our sample is $\$ 1.1$ million; mean TOTAL compensation is $\$ 1.9$ million (see Table 1 , column 1$)^{8}$ CEOs at undiversified firms (column 2) earn slightly lower average salaries and total compensation than their counterparts at diversified firms (column 3), although the differences are not statistically significant.

Firm Characteristics. We identify three firm characteristics as potentially important determinants of executive compensation levels: diversification, size, and financial performance.

Diversification. Data on a firm's major business activities are reported in the business segment section of the Securities and Exchange Commission 10-K reports beginning in 1977. The 1976 Financial Accounting Standards Board standard for reporting these data allows firms considerable latitude in defining business segments:

[N]o single set of characteristics is universally applicable in determining the industry segments of all enterprises, nor is any single characteristic determinative in all cases. Consequently, determination of an enterprise's industry segments must depend to a considerable extent of the judgement of the management of the enterprise. (SFAS No. 14, Paragraph 12)

While the standard rejects common classification schemes as inadequate, its language encourages identifying those businesses operating in distinct product markets as segments. Once segments are defined, companies are required to report segment data for all segments contributing at least 10 percent of the firm's revenue. No firm, therefore, is required to report data on more than ten segments.

${ }^{8}$ Dollar amounts are All inflated to 1990 constant dollars using the implicit GNP deflator. 
We obtain business segment data from COMPUSTAT's Industry Segment Files, which record seven years of segment data for each covered company. COMPUSTAT assigns a primary 4-digit SIC code to each reported segment and records revenues for most reported segments. We use these data to construct two indices of firm diversification." While they have different characteristics, we obtain qualitatively similar results for both measures.

The simplest diversification index is a count of the number of unique 4-digit SIC code segments reported for each year (NUMSEG). This index weights all segments equally. Distributions of firms and observations over NUMSEG are described in Table 2. Approximately one-third of our observations are for firms reporting only one segment, and multi-segment firms report 3.4 segments on average. ${ }^{10}$

A more complex diversification index, DIVERSE, incorporates information on the size distribution of segments. DIVERSE is defined as

$$
\text { DIVERSE }=1-\sum_{i=1}^{\text {NUMSEG }}\left[\frac{\text { segment sales }}{\text { company sales }}\right]^{2} \text {. }
$$

We also experimented with a third measure of diversification, which ranked as more diverse firms operating in industry segments that were "distant" from each other, similar in spirit to Gollop and Monahan (1991). We measured distance between a pair of industry segments by the probability of observing the given pair of industries within a single firm, using the universe of business segment data to construct probabilities. Because most of the probabilities were quite small, this measure had little power to distinguish among diversified firms.

${ }^{10}$ The number of reported segments declines slightly over time, from a mean of 2.79 in 1985 to a mean of 2.47 in 1990. This decline may reflect both a decline in firm diversification and a change in reporting behavior (see Lichtenberg, 1991). 
where segment sales are the sales reported for the business segment, and company sales is the sum of segment sales for the firm. This measure, which is one minus a Herfindahl index for the firm's business segments, increases (nonlinearly) in the number of segments, holding constant the variance of segment size, and declines in the variance of segment sales shares, holding constant the number of segments." Thus, a firm with two equal-sized segments is ranked as more diversified than a firm with two unequal segments. As a result, this index can be sensitive to the fact that a firm with two equal-sized segments may require different managerial inputs than a two-segment firm in which the larger segments represents 90 percent of sales. By construction, DIVERSE has a lower bound of zero (for single segment firms) and an upper bound of 0.90 (for a ten-segment firm with 10 percent of sales in each segment). The sample mean for DIVERSE is 0.32 , and the mean for firms with multiple segments is 0.48 . Because it is sensitive to both the number and size distribution of business segments, our initial analysis focuses on DIVERSE.

Firm Size. Measures of firm scale are included to account for the welldocumented relationship between compensation and firm size. ${ }^{12}$ Most studies measure scale by total company revenues (SALES); we also

"Similar measures have been used in a few earlier studies of diversification; see Ravenscraft and Scherer (1987), Gollop and Monahan (1991), and Comment and Jarrell (1992).

${ }^{12}$ The positive relationship between firm size and executive compensation is one of the more robust empirical regularities in the large literature on top executive pay. The formal ability matching models, beginning with Rosen (1982), have been motivated in part by a desire to explain this cross-sectional relationship. Others (e.g., Baker, Jensen and Murphy, 1988) have argued that the tendency of Boards of Directors to reward firm size may be an artifact of rule-of-thumb heuristics for determining CEO pay popularized by executive compensation consultants. 
consider controlling for the number of employees (EMPLOY). These two measures are highly correlated and, as the data reported in Table 1 show, the firms in our sample are quite large in both dimensions. Annual revenues average over $\$ 6$ billion in constant 1990 dollars, and the average firm has 40,000 employees. Diversified firms are larger on average than undiversified firms for both scale measures. ${ }^{13}$

Firm Financial Performance. While the theoretical and empirical literature suggests a positive correlation between firm financial performance and CEO pay, there is little consensus on the functional form of the relationship or the correct measures of profitability. Fortunately, our empirical analysis suggests that the diversification estimates are relatively robust to how we control for performance.

We consider two measures of firm profitability: the stock market rate of return on common equity (MKTROR) and the accounting rate of return on book equity (ACCROR). Despite the similarity in overall mean returns 1.18 for market and .15 for accounting), the correlation between these variables is only .24. While we report results from several performance specifications, the data appear to prefer a specification that includes current and lagged market and accounting returns in the determination of CEO compensation. Following Joskow and Rose (1994), we include one- and two-year lags in market return and one-year lags in accounting return. This implies that we can estimate the full model only for "experienced" CEOs, i.e., those who have held the office for more than two years.

${ }^{13}$ All noted differences in raw means between the diversified and undiversified subsamples are significant at the .01 level or better, unless otherwise noted. 
The full return specification includes a measure of stock price volatility to control for differences in compensation due to differential riskiness of firms' profit streams. Lower return variance may lessen the probability of large negative returns that could lead the Board to replace the CEO (Amihud and Lev, 1981) or lead to bankruptcy that terminates employment (Rose, 1992). Diversification also may reduce agency costs by improving the information available to the Board of Directors about the CEO's quality, thereby reducing the CEO's compensation risk (Aron, 1988, Hermalin and Katz, 1993). If the base salary includes an "insurance" component that reflects risk-return trade-offs, it should fall with reduced variance. Financial risk is indexed by the standard deviation of the firm's weekly stock market return over the fiscal year, SDRET.

Consistent with previous research (e.g., Montgomery and Wernerfelt, 1988; Lang and Stulz, 1993), average profitability is higher at the undiversified firms in our sample. The average market return is six percentage points higher at undiversified firms (22\% versus $16 \%$ for diversified firms); the average accounting return is two percentage points higher for these firms (16\% versus $14 \%$ for diversified firms). The higher mean returns at undiversified firms are associated with higher return variance. SDRET averages 4.6 percentage points for undiversified firms, compared to 4.1 percentage points for diversified firms.

CEO Characteristics. Prior work suggests that CEO age, tenure, and background may have significant effects on compensation levels. We use Forbes data to construct variables recording the chief executive's age when appointed CEO (AGE), years of tenure as a CEO (CEOTEN), a dummy variable equal to one if the CEO was hired from 
outside the firm (OUTSIDE), and a dummy variable equal to one if the CEO was the firm's founder (FOUNDER). ${ }^{14}$

There are notable differences in the distributions of CEO characteristics between diversified and undiversified firms. While most CEOs are promoted from within the firm, diversified firms are even less likely to hire outsiders than are undiversified firms (14\% versus $18 \%) .{ }^{15}$ Diversified firms' CEOs are on average four years older when they assume the CEO position than are those at undiversified firms. Perhaps because of this age difference, CEOs at diversified firms also have a shorter average tenure as CEOs 110.4 years versus 12.7 years for undiversified firms). ${ }^{10}$ There are very few founders in the sample, but the probability that the CEO is a founder is larger for single segment firms. This may reflect more specialized expertise, a greater commitment to the original line of business by founding CEOs, or differences in firm age.

Industry and Time Effects. CEO compensation is strongly influenced by industry norms and economy-wide movements in executive pay. (see Joskow, Rose, and Shepard, 1993). We introduce year fixed effects $\left(\delta_{t}\right)$ to control for aggregate shifts in real compensation levels over time. To accommodate differences in mean compensation levels across industries, we first classify similar two-digit SIC code industries into "industry groups"

${ }^{14}$ OUTSIDE is set equal to one for a CEO who was employed by the firm fewer than four years before appointment as CEO and who was not the firm's founder. The results are not sensitive to the four year cutoff.

${ }^{15}$ Significantly different at the .09 level.

10 Recall that these means are conditional on the CEO having more than 2 years of tenure, which is a criterion for inclusion in the experienced CEO panel. 
(see Appendix Table A1). We then calculate the share of the firm's revenues derived from each industry group for which it reports business segment sales in that year. The fixed effect for each observation is the weighted average of effects for each industry group, using these revenue shares as weights: ${ }^{17}$

$$
\text { WTGROUP }_{k}=\sum_{k=1}^{k} a_{k} \text { SHARE }_{k k,}
$$

where SHARE kit $_{\text {is }}$ the proportion of sales firm $j$ has attributed to business segments in industry group $k$ in year $t$, and $a_{k}$ is the industry fixed effect for a firm operating only in industry $k$.

\section{Econometric Specification}

For the full panel of experienced CEOs we estimate the following basic compensation equation:

$$
\begin{aligned}
& \text { In(CEO COMPENSATION } \left.N_{i k}\right)=\beta_{1} \text { DIVERSE }_{i k}+\beta_{2} \ln \left(\text { SALES }_{k i}\right)+\beta_{3}^{\prime} \text { RETURN }_{k i} \\
& +\beta_{4} \text { SDRET }_{i k}+\beta_{5} \text { CEOTEN }_{i n}+\beta_{6} \text { AGE }_{i} \\
& +\beta_{7} \text { OUTSIDE }+\beta_{8} \text { FOUNDER }_{\mathrm{f}} \\
& + \text { WTGROUP }_{n}+\delta_{i}+\epsilon_{\hat{n}} \text {. }
\end{aligned}
$$

where $i$ denotes the CEO, $j$ denotes the firm, and $t$ denotes the year. The CEO subscript has been added because we observe multiple CEOs for some firms. RETURN is a vector of firm performance measures (ACCROR,

${ }^{17}$ Some previous work has assigned each observation to a single industry group based on the primary SIC code for the firm las recorded by CRSP or COMPUSTAT). (f compensation at a diversified firm is based on the set of industries in which it operates rather than its primary industry oniy, this procedure could mis-estimate the diversification coefficient. When we estimate our model with only a primary industry effect, the diversification coefficients are slightly higher than, but otherwise quite similar to, those we report below. 
MKTROR and lags of these variables); $\beta_{3}{ }^{*}$ is the corresponding parameter vector.

This specification assumes a constant elasticity of compensation with respect to firm size, consistent with most previous studies. DIVERSE, CEO tenure, age at appointment, and financial performance all are assumed to have a constant proportional impact on compensation. OUTSIDE, FOUNDER, WTGROUP, and year effects $\left(\delta_{t}\right)$ shift the compensation curve up or down. The reported regressions adjust the standard error estimates for possible heteroskedasticity and within-CEO correlation in the error, $\epsilon^{10}{ }^{10}$

\section{N. RESULTS}

Results for several variants of the basic compensation equation are reported below. We first describe models of compensation estimated on our panel of 1505 observations on 480 experienced CEOs over 1985-1990. We then investigate whether the patterns we observe in this panel of experienced CEOs also apply to CEOs in their first year of tenure. This allows us to distinguish diversification effects due to job characteristics from those due to actions a CEO undertakes after assuming the top management position. Our third set of estimates analyzes the response of compensation to

${ }^{18}$ Both the ability model and some versions of the entrenchment model imply that the error contains a CEO-effect that is correlated with both diversification and compensation. In the case of ability models, this CEO-effect ("unobserved ability") is what drives the predicted positive cross-sectional correlation. Entrenchment effects ("CEO power") play a similar role in the "taste for diversification" explanations. The firstdifference specifications can be thought of as implicitly conditioning on (or removing) the CEO- or firm-specific component of the error. The implications of this conditioning vary across the ability and entrenchment explanations as described in section II. This is what gives the data power to distinguish empirically between the explanations. 
changes in diversification. These examine whether CEOs can raise their compensation by increasing the diversification of their firms. Finally, we explore alternative measures of diversification to identify the precise form of the compensation-diversification relationship.

\section{Pand Estimates of Diversification Premia}

Table 3 reports parameter estimates for variants of the compensation equation using our panel data set of 1505 CEO-years. In specifications reported here and the broad range of alternative specifications explored in preliminary analysis, CEO compensation increases with the level of diversification reported by the firm. This effect is both statistically and economically significant. Consider, for example, the effect of moving from an undiversified, single segment firm to the same size firm with two equalsized business segments, a move that increases DIVERSE from 0.0 to 0.5 , or about two standard deviations. An increase of this magnitude in DIVERSE is estimated to raise SALARY by about $12 \%$ (standard error of the estimate, $3 \%$; columns 2 through 41, and to raise TOTAL compensation by 13\% (standard error, $5 \%$; column 5 ). ${ }^{18}$ These proportions correspond to an increase of roughly $\$ 140,000$ in predicted salary and an increase of over $\$ 250,000$ in predicted total compensation, holding all else constant at the sample means. ${ }^{20}$ The point estimates of the DIVERSE coefficient generally are stable, although they tend to increase slightly with more

${ }^{19}$ To calculate the effect of this move in percentage terms, we compute exp ( $\left.0.5 \beta_{\text {DIVERSE }}\right)-1.0$.

20. If the error in our log-linear model of compensation is normally distributed, predicted compensation in dollars will be log-normal, and calculated as $\exp \left(X \beta+W T G R O U P+\delta_{t}+\right.$ variance $\left.(\epsilon) / 2\right)$. The corresponding compensation increases for a one standard deviation (.27) increase in DIVERSE are $\$ 75,000$ to $\$ 82,000$ in SALARY and over $\$ 143,000$ in TOTAL compensation. 
complete controls for firm financial performance; compare column 1 with column 2 , which adds current accounting return and lagged return variables to the model.

The other coefficients reported in Table $\mathbf{3}$ are consistent with earlier studies and largely unaffected by the inclusion of diversification measures. The elasticity of compensation with respect to firm size, measured by SALES, is about .25 (.01) for SALARY and .33 (.02) for TOTAL compensation. Including employees as an additional scale variable in column 4 adds little explanatory power and has no effect on the estimated diversification coefficient. ${ }^{21}$ This suggests the diversification premium is not due to simple differences in labor scale or intensity across diversified and undiversified firms.

CEO pay varies directly with both accounting and market returns, and the estimated sensitivity of pay to firm performance is much larger once lags in performance are included, consistent with results in Joskow and Rose (1994). In column 3, for example, increasing market return in the current year by 10 percentage points implies a SALARY increase of $1.2 \%(0.5 \%)$ in the current year, $1.7 \%(0.5 \%)$ in the next year, and $1.2 \%(0.4 \%)$ in the third year. An increase of 10 percentage points in current accounting return implies a $5.7 \%(1.6 \%)$ increase in current SALARY and a $3.5 \%(1.4 \%)$ increase in next year's SALARY. The estimated performance sensitivity is

21 We have experimented with specifications that replace SALES with book assets and employees, as in Joskow, Rose, and Shepard (1993). The size elasticity of .25 divides between assets and employees in these equations, and the DIVERSE coefficient tends to be slightly smaller and noisier, though in general within one standard error of the results in Table 3 . We also have experimented with specifications that allow the coefficient on In(SALES) to change as SALES increases. This yielded an almost constant elasticity of .25 across all SALES ranges and no change in the coefficient on DIVERSE. 
greater for TOTAL compensation (column 5), but the coefficient pattern is similar to that for SALARY.

The results indicate that compensation also increases with the variability of firm performance measures. Both SALARY and TOTAL compensation increase with the standard deviation of weekly market returns for the firm, SDRET. An increase in SDRET from four percentage points to five percentage points (one standard deviation increase from its sample mean) raises predicted SALARY by aimost $5 \%(1 \%)$ and TOTAL by aimost $6 \%$ (1.6\%). This is consistent with a pay premium for CEOs who bear more compensation risk through greater variability in their performance-based compensation or through an increased probability of termination resulting from very low performance realizations. Because SDRET is negatively correlated with diversification, including SDRET increases the estimated magnitude of the diversification effect slightly.

Finally, compensation varies in expected ways with CEO characteristics. There are modest age and tenure premiums. An additional year of age before becoming CEO raises SALARY by $0.4 \%(0.2 \%)$ and each additional year of tenure as CEO raises SALARY by $0.7 \%(0.2 \%$; column 3 ). These increments are in addition to the underlying upward trend in compensation over the late 1980s that is captured in the fixed year effects. ${ }^{22}$ Outside hires earn a $15 \%$ SALARY premium relative to internal hires, and founders realize SALARY discounts of about $13 \%$ relative to non-founders. The point estimates for the TOTAL compensation equation exhibit a similar pattern but tend to be somewhat larger in magnitude.

22 These are reported in Table A2 for the specifications in Table 3, columns 3 and 5 . 
The results in Table 3 generally are consistent with both ability-based and entrenchment-based explanations of executive compensation. In an efficient market for executive talent, compensation will be higher at more diversified and larger firms, assuming the marginal return to ability increases with diversification and firm size. Compensation is likely to increase with firm financial performance and with the risk of executive compensation streams, reflecting the outcome of efficient incentive contracts. Finally, positive age and tenure effects may be associated with the accumulation of human capital by top executives.

Positive diversification coefficients also would be expected if diversification is caused by investment undertaken by self-serving CEOs to increase their value to the firm, or if powerful CEOs have a taste for both diversification and compensation. In both these cases, the positive tenure coefficient might be interpreted as returns to managerial entrenchment that increases with tenure. ${ }^{23}$

\section{Compensation Equations for First-year CEOs}

Information on compensation during the CEO's first year of office may allow us to distinguish premia for higher ability from pay surpluses resulting from managerial entrenchment. If the diversification premium is a return to ability, it should be earned by CEOs in their first and all subsequent years of office. A positive first-year premium for diversification is less plausibly explained by the effects of managerial entrenchment models. First-year diversification premia should be smaller if the full panel result is due to CEO-

\footnotetext{
23 The positive correlation of pay with firm performance neither supports nor rejects entrenchment hypotheses. Although most managerial entrenchment models suggest reduced pay-for-performance sensitivity relative to optimal contracts, they need not imply zero correlation between pay and firm performance.
} 
specific investments, as in the Shleifer-Vishny model. A CEO may be able to alter the business mix over time to fit her/his unique abilities. But because a diversification program is likely to require some lead time, it is unlikely that new CEOs can alter their firm's business mix rapidly enough to affect the compensation they earn in their first year as CEO. Instead, the new CEO will be compensated based on her/his fit with the firm as shaped by the preceding CEO. ${ }^{24}$ Since the successor must be distinctly less wellsuited to that business mix for this strategy to raise the incumbent's compensation, the successor's premium from diversification should be much smaller. First-year premia also are likely to be smaller if the full panel result arises from the Board's inability to control a CEO who prefers diversification and high compensation. The Board is likely to have more bargaining power relative to new CEOs than relative to CEOs who have held that office long enough to affect the composition of the Board or to build a base of support among other top managers.

The last column of Table 1 reports descriptive statistics for the 172 CEOs we observe in their first full year of office. As would be expected, they earn less in SALARY and total compensation than do experienced CEOs. They also tend to be employed by slightly larger and more diversified firms than the average CEO in our experienced panel. This is consistent with shorter average tenure among diversified firms (compare columns 2 and 3 of Table 1), which implies over-representation of these firms in a new CEO sample.

${ }^{24}$ We have estimated equations that take this statement literally, by replacing the current value of DIVERSE for new CEOs with its value during the last year of the preceding CEO's tenure. The coefficient on DIVERSE increases slightly with this substitution, providing even further support for ability interpretations. 
Estimated compensation equations for this sample are presented in Table 4. ${ }^{25}$ The coefficient estimates for DIVERSE are quite similar to those reported for the experienced CEOs in Table 3, although the results are noisier for this smaller sample. A move from an single-segment firm to the same size firm with two equal business segments implies an increase of $11 \%(5 \%)$ in first year SALARY and $16 \%(7 \%)$ in first year TOTAL compensation, all else equal. This provides strong support for an ability premium interpretation of the diversification effect. These results provide no support for entrenchment explanations that are based either on actions the CEO undertakes or on managerial power that is an increasing function of tenure in position.

\section{Compensation Chenges for CEOs}

We can directly test the claim that CEOs diversify to improve their compensation by examining the effect of changes in diversification on changes in compensation. If CEOs diversify to increase their compensation, these changes should be positively correlated. If the panel and first-year CEO results represent payment to ability, however, the correlation between these changes for an incumbent CEO should be smaller than the correlation between levels of compensation and diversification.

To test these competing hypotheses, we estimate our basic compensation model in first differences. We have data on compensation, return, sales and diversification changes for 1005 CEO-years of the 1505 CEO-years in

25 The specification is based on column 3, Table 3, with three exceptions. First, CEO tenure is a constant (1) and therefore omitted. Second, only current performance measures are used because first-year CEOs have no prior performance. Third, the founder and SORET have been dropped because they are quite noisy and generally estimated as close to zero. 
our experienced CEO panel. ${ }^{28}$ Table 5 reports summary statistics for the variables included in the first difference model. These include changes in compensation, DIVERSE, In(SALES), and the rate of return measures. The remaining variables in the levels equation are either literally or nearly constant for a CEO over time and therefore are excluded from the first difference equations. ${ }^{27}$ The sample divides fairly evenly among increases, decreases, and no changes in DIVERSE. While most of the changes in DIVERSE are due to movements in segment shares rather than changes in the number of segments, the 147 observations with changes in the reported number of segments account for more than $80 \%$ of the total variation in DIVERSE.

Results for the first-differenced models are reported in Table 6. Columns 1 (Salary) and 3 Thotal) report results for first differences of our basic specification. The estimated compensation effect of increasing DIVERSE is negative and relatively substantial for both compensation measures. This suggests that the Boards rewarded specialization and penalized diversification during our sample period. The estimates imply that splitting an undiversified firm into two equal-size business segments (an increase of 0.5 in DIVERSE) would reduce SALARY by $8 \%(4.6 \%)$ and TOTAL

${ }^{26}$ Estimated compensation level equations for this sub-sample are quite similar to those for the full 1505 observation dataset, reported in Table 3. The coefficient on DIVERSE is slightly larger for the 1005 observation sub-sample, ranging from .24 (standard error, .08) to .28 (.07) in the salary specifications, but within one standard error of the results reported in Table 3.

27 The model includes year effects but not weighted industry effects. Including changes in the weighted industry fixed effects in the model does not affect the qualitative results but substantially increases the noisiness of the estimates. The differenced data do not appear to have sufficient power to estimate industry effects as well as the reported coefficients. 
compensation by $17 \%(12 \%)$. The point estimates are noisy, and can be bounded from zero only at the 0.10 level for the SALARY coefficient and 0.15 for TOTAL. But even a conservative interpretation of these estimates rejects the interpretation that increasing diversification will increase compensation, holding all else constant.

This pattern of results is robust to a broad variety of alternative first difference specifications we have explored, although the precision of the estimated coefficients declines as we ask more of the data. For example, we explored whether the negative correlation between diversification and compensation changes was due to failures of compensation to respond to size changes when both diversification and sales changed, or due to greater rewards for CEOs who focus the firm. To test this we allowed the coefficients on diversification and sales changes to depend on whether diversification increased, decreased, or remained constant. These results are reported in columns $\mathbf{2}$ and $\mathbf{4}$ of Table 5 . While the point estimates are noisy, they provide little support for these alternative explanations. ${ }^{28}$ In the SALARY regressions (column 2), for example, diversification changes appear to be associated with somewhat smaller elasticities of compensation with respect to sales. The penalty for diversifying and reward for focusing the firm are completely symmetric and unchanged in magnitude from the results in column 1, however.

These results are difficult to reconcile with managerial entrenchment explanations of diversification. In contrast to the predictions of the ShleiferVishny model, there is no premium to the CEO from "tailoring" the firm to fit the CEO. Changing the mix of the firm without substantially increasing

${ }^{28}$ Point estimates in the TOTAL regressions are more sensitive to this split and may in part consistent with the alternative explanations. Their substantial standard errors makes interpretation difficult, however. 
the scale of the firm reduces rather than increases the CEO's compensation. It is more difficult to empirically falsify the "taste" version of the entrenchment-based explanations, but our results suggest it may be costly for a CEO to indulge such a taste.

The implication of these results for overall compensation movements depends critically on what other changes accompany changes in diversification. The penalty for increases in diversification, for example, does not necessarily imply actual compensation declines if accompanied by sufficient increases in firm size. As Table 5 indicates, compensation increases on average even for CEOs who increase diversification, but by less than it does for CEOs who reduce diversification.

The negative DIVERSE coefficient indicates that disproportionately high growth in the firm's primary business (which reduces DIVERSE) is rewarded more than disproportionately high growth in secondary businesses (which increases DIVERSE), controlling for overall firm size. Alternatively, consider a single segment firm that adds a second segment of equal size, increasing DIVERSE by .50 and In(sales) by 1 . The coefficients in Column 1 imply a SALARY increment of $13 \%$. The same thought experiment for newly-hired CEOs (Table 4, Column 1) would imply a $32 \%$ salary increase. That is, a CEO hired by a firm with two equal-sized segments will earn $32 \%$ more than a CEO hired by a firm with one segment and half the sales. ${ }^{20}$ This pattern provides additional support for ability-based explanations. We find that the premium for diversification is much larger when the CEO is optimally-matched to the firm (i.e., when the estimates allow ability to vary

${ }^{29}$ Similar calculations can be made for the reverse move: focusing the firm. A CEO who sells one of two equal-sized business segments reduces DIVERSE and In(SALES) by 0.5 . The results in column 1 imply that the incumbent CEO's salary would fall by $2 \%$. The results for new CEOs in table 4 imply a decline of $24 \%$. 
with the level of diversification) than when the incumbent CEO is retained (i.e., hoiding the ability of the CEO fixed). This is what we would expect if ability-matching is the dominant source of the diversification premium. ${ }^{30}$

The negative correlation between changes in diversification and executive compensation is also consistent with market preferences for industrial focus or specialization over our sample period. Recent empirical research suggests that greater diversification was on average associated with reduced shareholder wealth during the late 1980s. Studies have concluded that diversified firms tend to be less profitable than comparable undiversified firms (Lang and Stulz, 1993; Montgomery and Wernerfelt, 1988); that the stock market reacts less favorably to diversifying acquisitions than to acquisitions of business closely related to the firm's existing line of business (Morck, Shleifer and Vishny, 1990). ${ }^{\text {in }}$ If executive compensation includes a component that rewards improvements to and penalizes degradation of firm performance beyond the response to changes in return, pay might adjust to reflect the expected outcomes of adding or subtracting diverse lines of business. This would imply a

${ }^{30}$ For example, because the incumbent CEO has higher ability than would be optimal for a newly focused firm, she/he is paid more than the alternative, well-matched and lower-ability candidate would be. Because the incumbent CEO has lower ability than would be optimal for a newly diversified firm, she/he is paid less than the alternative, well-matched and higher-ability candidate would be.

31 There is conflicting evidence on the effect of diversification on firm performance and on the stock market's reaction to diversification over time. For example, Matsusaka (1993) finds that the stock market responded positively to diversifying mergers in the 1960 s, and Morck, Shleifer and Vishny report that the negative reaction to diversifying mergers is more pronounced in the 1980s than in the 1970s. Studies finding a positive effect on firm performance from diversification also tend to be using data for periods prior to 1980. For our sample period, the most common finding is a negative share price reaction to diversification announcements. 
compensation penalty to increased diversification, as observed in Table 6. This result echoes Lambert and Larcker (1987), who find that CEOs can increase their compensation through acquisitions only if the acquisitions increase the shareholder value of the acquiring firm.

\section{The Form of the Diversification Premium}

The specifications estimated above assume that compensation increases proportionally with DIVERSE. While the qualitative patterns are robust to alternative measurements of diversification, the numerical estimates depend on the particular index we use. We have explored many formulations of the diversification measure and report results for two additional measures below. The first measure decomposes DIVERSE into two parts: one reflecting the number of segments and another the variance in segment size. The second measure is a count of the number of distinct business segments the firm reports (NUMSEG). Estimated diversification premia based on these measures are reported in Tables 7A and 7B. These substitutions for DIVERSE have no substantive effect on the remaining coefficients in the basic compensation equation, which are suppressed to limit the table size.

We first investigate whether compensation responds similarly to the number of different business segments and the size distribution of segments within the firm. This may provide some insight on how the complexity of the management task varies with diversification. We explore this question by decomposing DIVERSE, a measure of segment share concentration, into two terms. The first increases (nonlinearly) in the number of segments, the second decreases in the variance of segment size :

$$
\text { DIVERSE }=-\frac{1}{n}+\left(1-n \sigma^{2}\right)
$$


where $\sigma^{2}$ is the variance of segment revenue shares in the firm.

Table 7A reports results for this decomposition in the basic SALARY and TOTAL compensation specifications. The estimates suggest that the number component drives the entire DIVERSE result, with coefficients on the number component that are identical to those on DIVERSE itself (compare Table 7A to columns 3 and 5 in Table 3). The coefficient on the number component implies that a firm operating in two industry segments pays its CEO $12 \%$ more on average than an undiversified, single-segment firm, holding all else constant. Each additional segment is associated with progressively smaller increments to compensation, with an overall SALARY premium for a 10-segment firm of $21 \%$. The data do not suggest any effect of the variance component on compensation. ${ }^{32}$ This seems to imply that adding business segments increases the complexity of the management task even if the new activities are small relative to the original line of business.

We further explore the nonlinearity of compensation with respect to the number of segments in table 7B. In columns 1 (SALARY) and 3 (TOTAL), we report separate premia, relative to compensation at undiversified singlesegment firms, for each value of NUMSEG (2 through 10 segments). Because cell counts drop off quite sharply as the number of segments rise (see Table 2), we also consider estimates that pool across similar NUMSEG categories. These estimates are reported in columns 2 (SALARY) and 4 (TOTAL).

${ }^{32}$ Detailed investigation of this decomposition suggests that the variance component may influence compensation during the early years of CEO tenure, although the point estimates become quite noisy as the sample is subdivided in this way. The coefficient on the numbers component is quite stable across tenure categories. 
While the relationship between diversification and SALARY in Table 78 is nonlinear, it differs from the form imposed by the construction of DIVERSE. Diversified firms seem to partition roughly into three categories based on reported segment counts: two segments, three through five segments, and six or more segments. These categories form the basis of the estimates in column 2. Table 78. Moving from a single-segment to a two-segment firm adds $10 \%$ to SALARY. A further move into the 3-5 segment category adds an additional $7 \%$ premium relative to single segment firms, but no incremental premium for increased segments within this category. CEOs of the most diversified firms (6 through 10 segments) earn an additional $11 \%$ premium, implying a SALARY that is almost $30 \%$ higher than the SALARY for CEOs of undiversified firms, all else equal.

The pattern for TOTAL compensation (columns 3 and 4) seems to imply only two categories of diversified firms: those with two segments and those with three or more segments. The premium for adding a second segment to an undiversified firm is estimated at $17 \%$, substantially larger than the corresponding premium for SALARY. TOTAL compensation increases by another $3 \%$ when a third segment is added, but remains relatively flat thereafter (column 4). This suggests a smaller TOTAL compensation premium compared to the SALARY compensation premium at the most diversified firms. One should not overemphasize this distinction, however. The estimated diversification effects for TOTAL compensation are substantially noisier than those for SALARY compensation, and the point estimates generally are within a standard error of those we find in the SALARY regressions.

These results suggest that the distinction between diversified and undiversified enterprises is more significant than most distinctions within 
the class of diversified firms, with the possible exception of those few firms with highly diffuse operations (6 or more business segments). This pattern is consistent with a discrete jump in required managerial inputs when a firm changes from specialized (one-segment) to diversified. This could reflect changes in the hierarchical organization of the firm, the need for a substantively different type of chief executive, or both. The SALARY results for the most heavily-diversified firms, while based on small numbers of companies, suggest a further discrete change in the complexity of managing large numbers of distinct business segments.

\section{v. CONCLUSIONS}

During the late 1980s, firm diversification appears to have been associated with significantly higher compensation for the chief executive. CEOs of firms with two distinct lines of business earn on average $10 \%$ to $12 \%$ more than the salary and bonus paid to CEOs of similar but undiversified firms. This corresponds to an additional $\$ 115,000$ to $\$ 145,000$ per year relative to the mean salary and bonus for our sample of top CEOs. Moreover, the effect of diversification on compensation is as strong for first-year CEOs as for CEOs who have been on the job three or more years. This suggests that the diversification premium is a characteristic of the job and its demands, and not a result of changes instituted by incumbent managers to increase their value to the firm or to pursue their own agendas.

For a given CEO, increases in diversification during out sample period, holding all else constant, appear to reduce rather than increase compensation. This appears inconsistent with CEOs undertaking diversification to increase their compensation. While it is difficult to falsify

the hypothesis that CEOs diversify because they have a taste for diversification, indulging this taste may be costly for the CEO. The change regressions suggest that the average CEO has insufficient control to 
diversify the corporation without paying a price in foregone compensation compared to what could be earned by increasing growth in the core business.

Our findings support an interpretation of diversification premia as rents earned by high-ability CÉOs. If diversification increases the marginal return to ability, an efficient labor market will allocate higher ability CEOs to more diversified firms where they will earn a higher compensation. This is consistent with the premium observed for experienced CEOs and the equally high premium for first-year CEOs. The lower increments to changes in diversification for incumbent CEOs are also consistent with matching models with turnover costs. Because turnover is costly for both the firm and the incumbent, bargaining produces an increment that is smaller than would be observed if the salaries of two well-matched CEOs were compared.

While this study provides direct evidence only on the relationship between diversification and executive compensation, it may provide some clues to the source of the disappointing performance of many diversified firms. If ability-matching is a critical determinart of compensation patterns across firms, our results suggest that diversified firms may simply be more difficult to manage successfully. 


\section{REFERENCES}

Amihud, Y. and B. Lev. "Risk Reduction as a Managerial Motive for Conglomerate Mergers." Bell Journal of Economics, Vol. 12 (1981), pp. 605-617.

Aron, D.J. "Ability, Moral Hazard, Firm Size and Diversification." Rand Joumal of Economics, Vol. 19 (1988), pp. 72-87.

Baker, G.F., Jensen, M.C. and Murphy, K.J. "Compensation and Incentives: Practice vs. Theory." Joumal of Finance, Vol. 43 (1988), pp. 593-616.

Comment, R. and Jarrell, G. A. "Corporate Focus, Stock Returns, and the Market for Corporate Control." Bradley Policy Research Center Managerial Economics Research Studies Working Paper MR 91-01, University of Rochester, May 1992.

Finkelstein, S. and Hambrick, D.C. "Chief Executive Compensation: A Study of the Intersection of Markets and Political Processes." Strategic Management Journal, Vol. 10 (1989), pp. 121-34.

Gollop, F.M. and Monahan, J.L. "A Generalized Index of Diversification: Trends in U.S. Manufacturing." Review of Economics and Statistics, Vol. xx (1991), pp. 318-330.

Hermalin, B.E. and Katz, M.L. "Corporate Diversification and Agency," mimeo, 1993, UC Berkeley.

Jensen, M.C. and Murphy, K.J. "Performance Pay and Top Management Incentives." Journal of Political Economy, Vol. 98 (1990), pp. 225-64.

Joskow, P.L. and Rose, N.L. "Pay-for-Performance: A Reassessment," mimeo, 1994, MIT.

Joskow, P., Rose, N. and Shepard, A. "Regulatory Constraints on CEO Compensation." Brookings Papers on Economic Activity: Microeconomics, No. 1, 1993, pp. 1-58.

Lambert, R.A. and Larcker, D.F. "Executive Compensation Effects of Large Corporate Acquisitions," Journal of Accounting and Public Policy, Vol. 6 (1987). pp. 231-242.

Lang, L.H.P. and Stulz, R.M. "Tobin's Q, Corporate Diversification and Firm Performance." NBER Working Paper No. 4376, June 1993. 
Lichtenberg, F.R. "The Managerial Response to Regulation of Financial Reporting for Segments of a Business Enterprise." Journal of Regulatory Economics, Vol 3 (1991), pp. 241-249.

Mace, M.L. Directors: Myth and Reality. Division of Research, Graduate School of Business Administration, Cambridge MA, Harvard University, 1971.

Matsusaka, J. G. "Takeover Motives During the Conglomerate Merger Wave," Rand Journal of Economics, Vol. 24 (1993), pp. 357-379.

Montgomery, C.A. and Wernerfelt, B. -Diversification, Ricardian Rents, and Tobin's q." Rand Joumal of Economics, Vol. 19 (1988), pp. 623-632.

Morck, R., Shleifer, A. and Vishny, R.W. "Do Managerial Objectives Drive Bad Acquisitions." Joumal of Finance, Vol 45 (1990), pp. 31-48.

Ravenscraft, D. J. and Scherer, F. M. Mergers, Sell-offs, and Economic Efficiency. Washington, D. C.: The Brookings Institution, 1987.

Roll. R. "The Hubris Hypothesis of Corporate Takeovers." Joumal of Business, Vol. 59 (1986), pp. 197-216.

Rose, D.C. "Bankruptcy Risk, Firm-Specific Managerial Human Capital, and Diversification." Review of Industrial Organization, Vol. 7 (1992), pp. 6573.

Rosen, S. "Authority, Control and the Distribution of Earnings." Bell Joumal of Economics, Vol. 13 (1982), pp. 311-323.

Rosen, S. "Contracts and the Market for Executives." In L. Wernin and $\mathrm{H}$. Wijkander, eds., Contract Economics. Oxford: Basil Blackwell, 1992.

Shleifer, A. and Vishny, R.W. Management Entrenchment: The Case of Manager-Specific Investments." Journal of Financial Economics, Vol. 25 (1989), pp. 123-39.

Waldman, M. "Worker Allocation, Hierarchies and the Wage Distribution." Review of Economic Studies, Vol. 51 (1984), pp. 95-109. 
Tablo 1: Descriptive Statistics

\begin{tabular}{|c|c|c|c|c|}
\hline \multirow[b]{2}{*}{ Voriablo } & \multicolumn{3}{|c|}{ Experienced CEO Panel } & \multirow{2}{*}{$\begin{array}{c}\text { First-yoar } \\
\text { CEOs }\end{array}$} \\
\hline & All Obs. & $\begin{array}{l}\text { Single } \\
\text { Segment }\end{array}$ & $\begin{array}{l}\text { Multiple } \\
\text { Segmont }\end{array}$ & \\
\hline $\begin{array}{l}\text { Salery and bonus, } \\
\text { thousands of } 1990 \\
\text { dollers (SALARY) }\end{array}$ & $\begin{array}{l}1067.40 \\
(934.88)\end{array}$ & $\begin{array}{c}1010.31 \\
(1231.18)\end{array}$ & $\begin{array}{l}1095.56 \\
(745.89)\end{array}$ & $\begin{array}{c}774.08 \\
(294.81)\end{array}$ \\
\hline $\begin{array}{l}\text { Totel compensation, } \\
\text { thousands of } 1990 \\
\text { dollars (TOTAL) }\end{array}$ & $\begin{array}{c}1871.83 \\
(2955.24)\end{array}$ & $\begin{array}{c}1802.24 \\
(3907.71)\end{array}$ & $\begin{array}{c}1906.13 \\
(2349.22)\end{array}$ & $\begin{array}{r}1173.30 \\
(1019.86)\end{array}$ \\
\hline $\begin{array}{l}\text { Number segments } \\
\text { reported (NUMSEG) }\end{array}$ & $\begin{array}{c}2.60 \\
(1.59)\end{array}$ & 1.00 & $\begin{array}{c}3.39 \\
(1.37)\end{array}$ & $\begin{array}{c}2.89 \\
(1.58)\end{array}$ \\
\hline $\begin{array}{l}\text { Seles-woighted } \\
\text { diversification } \\
\text { (DIVERSE) }\end{array}$ & $\begin{array}{c}0.32 \\
(0.27)\end{array}$ & 0.00 & $\begin{array}{l}0.48 \\
(0.19)\end{array}$ & $\begin{array}{c}0.38 \\
(0.27)\end{array}$ \\
\hline $\begin{array}{l}\text { Selee, millions of } 1990 \\
\text { dollars (SALES) }\end{array}$ & $\begin{array}{c}6026.71 \\
11699.99)\end{array}$ & $\begin{array}{c}5261.14 \\
(12557.11)\end{array}$ & $\begin{array}{c}6404.18 \\
(11240.68)\end{array}$ & $\begin{array}{c}8641.47 \\
(16238.68)\end{array}$ \\
\hline $\begin{array}{l}\text { Number of omployoes, } \\
\text { thousands (EMPLOY) }\end{array}$ & $\begin{array}{c}40.23 \\
(69.05)\end{array}$ & $\begin{array}{c}33.11 \\
(60.03)\end{array}$ & $\begin{array}{c}43.73 \\
(72.86)\end{array}$ & $\begin{array}{c}53.42 \\
(89.43)\end{array}$ \\
\hline $\begin{array}{l}\text { Market roturn } \\
\text { (MKTROR) }\end{array}$ & $\begin{array}{l}0.18 \\
(0.33)\end{array}$ & $\begin{array}{c}0.22 \\
(0.42)\end{array}$ & $\begin{array}{l}0.16 \\
(0.28)\end{array}$ & $\begin{array}{l}0.16 \\
(0.33)\end{array}$ \\
\hline $\begin{array}{l}\text { Accounting return } \\
\text { (ACCROR) }\end{array}$ & $\begin{array}{c}0.15 \\
(0.12)\end{array}$ & $\begin{array}{l}0.16 \\
(0.11)\end{array}$ & $\begin{array}{l}0.14 \\
(0.13)\end{array}$ & $\begin{array}{c}0.11 \\
(0.14)\end{array}$ \\
\hline $\begin{array}{l}\text { Standard doviation of } \\
\text { wookly markot returns } \\
\text { (SDAET) }\end{array}$ & $\begin{array}{l}0.04 \\
(0.01)\end{array}$ & $\begin{array}{c}0.05 \\
(0.01)\end{array}$ & $\begin{array}{l}0.04 \\
(0.01)\end{array}$ & $\begin{array}{l}0.04 \\
(0.02)\end{array}$ \\
\hline $\begin{array}{l}\text { CEO age at } \\
\text { appointmont (AGE) }\end{array}$ & $\begin{array}{l}47.53 \\
(8.78)\end{array}$ & $\begin{array}{l}44.71 \\
(9.45)\end{array}$ & $\begin{array}{l}48.92 \\
(8.09)\end{array}$ & $\begin{array}{c}53.29 \\
(6.12)\end{array}$ \\
\hline $\begin{array}{l}\text { Tonuro as CEO } \\
\text { (CEOTEN) }\end{array}$ & $\begin{array}{l}11.17 \\
(8.38)\end{array}$ & $\begin{array}{l}12.72 \\
(9.23)\end{array}$ & $\begin{array}{l}10.41 \\
(7.82)\end{array}$ & 1.00 \\
\hline $\begin{array}{l}\text { Outside hire } \\
\text { (OUTSIDE) }\end{array}$ & 0.16 & 0.18 & 0.14 & .14 \\
\hline $\begin{array}{l}\text { Cormpeny founder } \\
\text { (FOUNDER) }\end{array}$ & 0.12 & 0.24 & 0.05 & .02 \\
\hline $\begin{array}{l}\text { Number of observations } \\
\text { Number of firms }\end{array}$ & $\begin{array}{c}1505 \\
403\end{array}$ & $\begin{array}{l}497 \\
157\end{array}$ & $\begin{array}{c}1008 \\
281\end{array}$ & $\begin{array}{l}172 \\
159\end{array}$ \\
\hline
\end{tabular}

Standard deviations aro in parentheses. All dollar amounts are infletod to 1990 constant dollars using the implicit GNP deflator. 
Table 2: Distribution of Diversification in Sample

\begin{tabular}{|c|c|c|}
\hline $\begin{array}{l}\text { Number of reported } \\
\text { 4-digit SIC segments }\end{array}$ & $\begin{array}{c}\text { Number of } \\
\text { observations }\end{array}$ & $\begin{array}{c}\text { Number of Firms } \\
\text { reporting } n \\
\text { segments in any } \\
\text { year }\end{array}$ \\
\hline 1 & 497 & 157 \\
\hline 2 & 296 & 107 \\
\hline 3 & 323 & 144 \\
\hline 4 & 212 & 100 \\
\hline 5 & 110 & 48 \\
\hline 6 & 35 & 18 \\
\hline 7 & 20 & 11 \\
\hline 8 & 4 & 4 \\
\hline 9 & 3 & 3 \\
\hline 10 & 5 & 1 \\
\hline Total & 1505 & 593 \\
\hline
\end{tabular}


Table 3: Determinants of Compensation

$N=1505$ CEO-years

\begin{tabular}{|c|c|c|c|c|c|}
\hline \multirow{2}{*}{ Veriable } & \multicolumn{4}{|c|}{ In(Salary \& Bonus Compensation) } & \multirow{2}{*}{$\begin{array}{c}\ln \text { (Total) } \\
5\end{array}$} \\
\hline & 1 & 2 & 3 & 4 & \\
\hline $\begin{array}{l}\text { Diversification } \\
\text { Index (DIVERSE) }\end{array}$ & $\begin{array}{l}.182 \\
(.071)\end{array}$ & $\begin{array}{l}.219 \\
(.067)\end{array}$ & $\begin{array}{c}.233 \\
(.066)\end{array}$ & $\begin{array}{c}.241 \\
(.067)\end{array}$ & $\begin{array}{l}.249 \\
(.095)\end{array}$ \\
\hline In(Sales) & $\begin{array}{l}.243 \\
(.022)\end{array}$ & $\begin{array}{l}.252 \\
(.021)\end{array}$ & $\begin{array}{l}.264 \\
(.021)\end{array}$ & $\begin{array}{l}.280 \\
(.059)\end{array}$ & $\begin{array}{l}.325 \\
(.031)\end{array}$ \\
\hline In(Employees) & & & & $\begin{array}{l}-.018 \\
(.056)\end{array}$ & \\
\hline Merket Return & $\begin{array}{l}.161 \\
(.051)\end{array}$ & $\begin{array}{l}.125 \\
(.052)\end{array}$ & $\begin{array}{l}.123 \\
(.053)\end{array}$ & $\begin{array}{l}.121 \\
(.053)\end{array}$ & $\begin{array}{l}.162 \\
(.067)\end{array}$ \\
\hline $\begin{array}{l}\text { Merket Roturn. } \\
\text { yoer t-1 }\end{array}$ & & $\begin{array}{l}.178 \\
(.053)\end{array}$ & $\begin{array}{l}.165 \\
(.053)\end{array}$ & $\begin{array}{l}.165 \\
(.053)\end{array}$ & $\begin{array}{r}.233 \\
(.072)\end{array}$ \\
\hline $\begin{array}{l}\text { Merket Return. } \\
\text { yoor t-2 }\end{array}$ & & $\begin{array}{l}.143 \\
(.043)\end{array}$ & $\begin{array}{l}.122 \\
(.041)\end{array}$ & $\begin{array}{l}.122 \\
(.042)\end{array}$ & $\begin{array}{l}.267 \\
(.063)\end{array}$ \\
\hline $\begin{array}{l}\text { Accounting } \\
\text { Return on Equity }\end{array}$ & & $\begin{array}{c}.500 \\
(.164)\end{array}$ & $\begin{array}{l}.565 \\
(.164)\end{array}$ & $\begin{array}{l}.564 \\
(.163)\end{array}$ & $\begin{array}{c}.967 \\
(.243)\end{array}$ \\
\hline $\begin{array}{l}\text { Accounting } \\
\text { roturn, } \\
\text { yoar t-1 }\end{array}$ & & $\begin{array}{l}.278 \\
(.146)\end{array}$ & $\begin{array}{l}.353 \\
(.139)\end{array}$ & $\begin{array}{l}.346 \\
(.135)\end{array}$ & $\begin{array}{l}.597 \\
(.209)\end{array}$ \\
\hline $\begin{array}{l}\text { Std. dev. of } \\
\text { market return }\end{array}$ & & & $\begin{array}{c}4.887 \\
(1.574)\end{array}$ & $\begin{array}{c}4.813 \\
(1.563)\end{array}$ & $\begin{array}{c}5.823 \\
(2.016)\end{array}$ \\
\hline Tonuro as CEO & $\begin{array}{l}.005 \\
(.004)\end{array}$ & $\begin{array}{l}.007 \\
(.004)\end{array}$ & $\begin{array}{l}.007 \\
(.004)\end{array}$ & $\begin{array}{l}.008 \\
(.004)\end{array}$ & $\begin{array}{l}.010 \\
(.005)\end{array}$ \\
\hline $\begin{array}{l}\text { CEO age et } \\
\text { Appointment }\end{array}$ & $\begin{array}{l}.002 \\
(.004)\end{array}$ & $\begin{array}{l}.003 \\
(.004)\end{array}$ & $\begin{array}{c}.004 \\
(.004)\end{array}$ & $\begin{array}{l}.004 \\
(.004)\end{array}$ & $\begin{array}{c}.008 \\
(.004)\end{array}$ \\
\hline Outside Hire & $\begin{array}{c}.154 \\
(.073)\end{array}$ & $\begin{array}{c}.142 \\
(.068)\end{array}$ & $\begin{array}{l}.141 \\
(.068)\end{array}$ & $\begin{array}{c}.139 \\
(.066)\end{array}$ & $\begin{array}{c}.179 \\
(.084)\end{array}$ \\
\hline Founder & $\begin{array}{l}-.063 \\
(.103)\end{array}$ & $\begin{array}{l}-.105 \\
(.099)\end{array}$ & $\begin{array}{l}-.143 \\
(.100)\end{array}$ & $\begin{array}{l}-.146 \\
(.098)\end{array}$ & $\begin{array}{l}-.290 \\
(.130)\end{array}$ \\
\hline SSR & $\begin{array}{c}279.13 \\
.32\end{array}$ & $\begin{array}{c}257.31 \\
.32\end{array}$ & $\begin{array}{c}253.47 \\
.38\end{array}$ & $\begin{array}{c}253.38 \\
.38\end{array}$ & $\begin{array}{c}578.82 \\
.33\end{array}$ \\
\hline
\end{tabular}

All regressions include year and woighted SIC fixed offocts.

Asymptotic robust standerd errors in parentheses. 
Table 4: Determinants of Compensation, First-Year CEOs $N=172$ CEOs

\begin{tabular}{l|cc} 
Variable & $\begin{array}{c}\text { In(Salary \& } \\
\text { Bonus) }\end{array}$ & $\begin{array}{c}\text { In(Total } \\
\text { Compensation) }\end{array}$ \\
\hline Diversification & .206 & .297 \\
Index (DIVERSE) & $(.090)$ & $(.139)$ \\
In(Sales) & .178 & .270 \\
Market Return & $(.022)$ & $1.040)$ \\
& .026 & .094 \\
Accounting Return & $1.082)$ & $(.124)$ \\
& .600 & .844 \\
Age at Appointment & $1.195)$ & $1.332)$ \\
& .005 & -.003 \\
Outside Hire & $1.004)$ & $1.007)$ \\
& -.087 & .028 \\
SSR & $1.066)$ & $1.133)$ \\
& 1.15 & 35.45 \\
\hline
\end{tabular}

All regressions include year and weighted SIC fixed effects. Asymptotic robust standard errors in parentheses. 
Table 5: Descriptive Statistics, First Differences

\begin{tabular}{|c|c|c|c|}
\hline Variable & $\begin{array}{c}\text { All } \\
\text { Observations }\end{array}$ & $\begin{array}{l}\text { Observations } \\
\text { with Increase } \\
\text { in DIVERSE }\end{array}$ & $\begin{array}{c}\text { Observations } \\
\text { with Decrease } \\
\text { in DIVERSE }\end{array}$ \\
\hline$\Delta \ln$ (Salary \& Bonus) & $\begin{array}{l}.064 \\
(.223)\end{array}$ & $\begin{array}{l}.046 \\
(.204)\end{array}$ & $\begin{array}{l}.078 \\
(.222)\end{array}$ \\
\hline $\begin{array}{l}\Delta \ln (\text { Total } \\
\text { Compensation) }\end{array}$ & $\begin{array}{l}.111 \\
(.650)\end{array}$ & $\begin{array}{l}.098 \\
(.651)\end{array}$ & $\begin{array}{l}.130 \\
(.651)\end{array}$ \\
\hline$\triangle$ DIVERSE & $\begin{array}{l}-.001 \\
(.078)\end{array}$ & $\begin{array}{l}.048 \\
(.088)\end{array}$ & $\begin{array}{l}-.045 \\
(.075)\end{array}$ \\
\hline $\begin{array}{l}\Delta \text { Number of } \\
\text { Segments }\end{array}$ & $\begin{array}{l}-.027 \\
(.503)\end{array}$ & $\begin{array}{l}.185 \\
(.590)\end{array}$ & $\begin{array}{l}-.238 \\
(.550)\end{array}$ \\
\hline $\begin{array}{l}\text { Number of } \\
\text { Observations with } \\
\text { non-zero } \Delta \text { Number of } \\
\text { Segments }\end{array}$ & 147 & 56 & 75 \\
\hline$\Delta \ln$ (Sales) & $\begin{array}{l}.072 \\
(.154)\end{array}$ & $\begin{array}{c}.072 \\
(.166)\end{array}$ & $\begin{array}{l}.045 \\
(.158)\end{array}$ \\
\hline$\Delta$ Market Return & $\begin{array}{l}-.108 \\
(.440)\end{array}$ & $\begin{array}{l}-.104 \\
(.374)\end{array}$ & $\begin{array}{l}-.096 \\
(.349)\end{array}$ \\
\hline$\Delta$ Accounting Return & $\begin{array}{l}-.004 \\
(.088)\end{array}$ & $\begin{array}{l}-.003 \\
(.089)\end{array}$ & $\begin{array}{l}-.002 \\
(.088)\end{array}$ \\
\hline $\begin{array}{l}\text { Number of } \\
\text { Observations }\end{array}$ & 1005 & 325 & 366 \\
\hline
\end{tabular}

Standard deviations are in parentheses. 
Table 6: Determinants of Changes in Compensation

$$
N=1005
$$

\begin{tabular}{|c|c|c|c|c|}
\hline \multirow{2}{*}{$\frac{\text { Variable }}{\text { DDIVERSE }}$} & \multicolumn{2}{|c|}{$\begin{array}{c}\Delta \ln (\text { Salary \& } \\
\text { Bonus) }\end{array}$} & \multicolumn{2}{|c|}{$\begin{array}{c}\Delta \ln (T o t a l \\
\text { Compensation) }\end{array}$} \\
\hline & $\begin{array}{l}-.166 \\
(.090)\end{array}$ & & $\begin{array}{l}-.374 \\
(.228)\end{array}$ & \\
\hline $\begin{array}{l}\triangle D I V E R S E, \text { if } \\
\text { DIVERSE falls }\end{array}$ & & $\begin{array}{l}-.155 \\
(.140)\end{array}$ & & $\begin{array}{l}-.534 \\
(.352)\end{array}$ \\
\hline $\begin{array}{l}\triangle D I V E R S E, \text { if } \\
\text { DIVERSE increases }\end{array}$ & & $\begin{array}{l}-.160 \\
(.127)\end{array}$ & & $\begin{array}{l}.052 \\
(.255)\end{array}$ \\
\hline$\Delta$ in (Sales) & $\begin{array}{l}.208 \\
(.062)\end{array}$ & & $\begin{array}{l}.337 \\
(.135)\end{array}$ & \\
\hline $\begin{array}{l}\text { Aln(Sales), if } \\
\text { DIVERSE falls }\end{array}$ & & $\begin{array}{l}.137 \\
(.093)\end{array}$ & & $\begin{array}{l}.456 \\
(.156)\end{array}$ \\
\hline $\begin{array}{l}\triangle \ln \text { (Sales), if } \\
\text { DIVERSE is } \\
\text { unchanged }\end{array}$ & & $\begin{array}{l}.325 \\
(.107)\end{array}$ & & $\begin{array}{l}.573 \\
(.192)\end{array}$ \\
\hline $\begin{array}{l}\triangle \ln \text { (Sales), if } \\
\text { DIVERSE increases }\end{array}$ & & $\begin{array}{l}.192 \\
(.078)\end{array}$ & & $\begin{array}{l}-.004 \\
(.156)\end{array}$ \\
\hline$\Delta$ Market Return & $\begin{array}{l}.064 \\
(.028)\end{array}$ & $\begin{array}{l}.067 \\
(.028)\end{array}$ & $\begin{array}{l}.150 \\
(.063)\end{array}$ & $\begin{array}{l}.154 \\
(.065)\end{array}$ \\
\hline $\begin{array}{l}\Delta \text { Market Return, year } \\
t-1\end{array}$ & $\begin{array}{l}.088 \\
(.025)\end{array}$ & $\begin{array}{l}.091 \\
(.025)\end{array}$ & $\begin{array}{l}.235 \\
(.066)\end{array}$ & $\begin{array}{l}.236 \\
(.067)\end{array}$ \\
\hline $\begin{array}{l}\Delta \text { Market Return, year } \\
t-2\end{array}$ & $\begin{array}{l}.029 \\
(.023)\end{array}$ & $\begin{array}{l}.028 \\
(.022)\end{array}$ & $\begin{array}{l}.189 \\
(.052)\end{array}$ & $\begin{array}{l}.186 \\
(.053)\end{array}$ \\
\hline AAccounting Return & $\begin{array}{l}.508 \\
(.112)\end{array}$ & $\begin{array}{l}.511 \\
(.111)\end{array}$ & $\begin{array}{l}.659 \\
(.257)\end{array}$ & $\begin{array}{l}.662 \\
(.253)\end{array}$ \\
\hline $\begin{array}{l}\Delta \text { Accounting Return, } \\
\text { year } t-1\end{array}$ & $\begin{array}{l}.180 \\
(.081)\end{array}$ & $\begin{array}{l}.183 \\
(.081)\end{array}$ & $\begin{array}{c}.065 \\
(.182)\end{array}$ & $\begin{array}{l}.060 \\
(.183)\end{array}$ \\
\hline $\begin{array}{l}\text { SSR } \\
\text { Adjusted } R^{2}\end{array}$ & $\begin{array}{c}43.27 \\
.12\end{array}$ & $\begin{array}{c}43.11 \\
.12\end{array}$ & $\begin{array}{c}401.58 \\
.04\end{array}$ & $\begin{array}{c}400.01 \\
.04\end{array}$ \\
\hline
\end{tabular}

All regressions include year fixed effects.

Asymptotic robust standard errors in parentheses. 
Table 7A: Decomposition of DIVERSE Effects

$N=1505$ CEO-Years

\begin{tabular}{l|cc}
$\begin{array}{l}\text { Diversification } \\
\text { Component }\end{array}$ & In(Salary \& Bonus) & $\begin{array}{c}\text { In(Total } \\
\text { Compensation) }\end{array}$ \\
\hline$-1 /$ (Number of & .233 & .249 \\
Segments) & $1.066)$ & $1.095)$ \\
$1-$ Segment & .033 & .041 \\
Variance & $1.122)$ & $1.170)$ \\
Component &. & \\
SSR & 252.45 & 577.72 \\
Adjusted R2 & .38 & .34 \\
\hline
\end{tabular}

All regressions include the remaining variables reported in columns 3 and 5 of Table 3 as well as year and woighted industry group fixed effects. Asymptotic robust standard errors in parentheses. 
Table 7B: Diversification Effects by Number of Segments $\mathrm{N}=1505$ CEO-Years

\begin{tabular}{|c|c|c|c|c|}
\hline \multirow{2}{*}{$\begin{array}{l}\text { Number of } \\
\text { Segments }\end{array}$} & \multicolumn{2}{|c|}{ In(Salary \& Bonus) } & \multicolumn{2}{|c|}{$\begin{array}{c}\ln (\text { Total } \\
\text { Compensation) }\end{array}$} \\
\hline & 1 & 2 & 3 & 4 \\
\hline 2 & $\begin{array}{l}.092 \\
(.051)\end{array}$ & $\begin{array}{l}.091 \\
(.051)\end{array}$ & $\begin{array}{l}.156 \\
(.074)\end{array}$ & $\begin{array}{l}.154 \\
(.074)\end{array}$ \\
\hline 3 & $\begin{array}{l}.163 \\
(.054)\end{array}$ & & $\begin{array}{l}.215 \\
(.072)\end{array}$ & \\
\hline 4 & $\begin{array}{c}.153 \\
(.047)\end{array}$ & $\begin{array}{l}.157 \\
(.046)\end{array}$ & $\begin{array}{c}.184 \\
(.070)\end{array}$ & $\begin{array}{c}.183 \\
(.064)\end{array}$ \\
\hline 5 & $\begin{array}{l}.151 \\
(.056)\end{array}$ & & $\begin{array}{l}.087 \\
(.082)\end{array}$ & \\
\hline 6 & $\begin{array}{l}.239 \\
(.093)\end{array}$ & & $\begin{array}{l}.131 \\
(.108)\end{array}$ & \\
\hline 7 & $\begin{array}{l}.183 \\
(.067)\end{array}$ & & $\begin{array}{l}.063 \\
(.104)\end{array}$ & \\
\hline 8 & $\begin{array}{l}-.022 \\
(.117)\end{array}$ & $\begin{array}{l}.259 \\
(.080)\end{array}$ & $\begin{array}{c}.083 \\
(.139)\end{array}$ & $\begin{array}{l}.184 \\
(.104)\end{array}$ \\
\hline 9 & $\begin{array}{l}1.161 \\
(.710)\end{array}$ & & $\begin{array}{l}.997 \\
(.751)\end{array}$ & \\
\hline 10 & $\begin{array}{l}.442 \\
(.092)\end{array}$ & & $\begin{array}{l}.649 \\
(.649)\end{array}$ & \\
\hline $\begin{array}{c}S S R \\
R^{2}\end{array}$ & $\begin{array}{c}248.94 \\
.39\end{array}$ & $\begin{array}{l}251.93 \\
.42\end{array}$ & $\begin{array}{c}572.18 \\
.34\end{array}$ & $\begin{array}{c}576.88 \\
.34\end{array}$ \\
\hline
\end{tabular}

All regressions include the variables reported in column 3 of Table 3 as well as year and weighted SIC industry group fixed effects. Diversification premia relative to single segment firms are calculated as exp(coefficient) - 1 . Asymptotic robust standard errors in parentheses. 
Appendix Table A1: Industry Classification and Fixed Effects

\begin{tabular}{|c|c|c|}
\hline Cotogory & $\begin{array}{l}\text { Sic Codes Included } \\
\text { in Group }\end{array}$ & $\begin{array}{l}\text { Estimated Fixe d } \\
\text { Effocts }\end{array}$ \\
\hline Agriculture, Forestry \& Fishing & 01.09 & $-1.444 \quad(.727)$ \\
\hline Mining & $10,12,14$ & $-.029 \quad(.135)$ \\
\hline Oil and Gas Extraction & 13 & $.211 \quad(.233)$ \\
\hline Construction & $15,16,17$ & $-.147 \quad(.145)$ \\
\hline Food \& Kindred Products & 20 & $.131 \quad(.104)$ \\
\hline Papor \& Alllod Products & 26 & $-.070 \quad(.094)$ \\
\hline Printing \& Publishing & 27 & $-.037 \quad(.105)$ \\
\hline Chomicels \& Allied Products & 28 & $.204 \quad(.079)$ \\
\hline $\begin{array}{l}\text { Potroloum Refining \& Releted } \\
\text { Industrios }\end{array}$ & 29 & $-.158 \quad(.121)$ \\
\hline Othor Manufacturing & $21-25,30-32,39$ & $.234 \quad(.136)$ \\
\hline Motals & 33,34 & $-.152(.134)$ \\
\hline Machinory \& Computers & 35 & bese group \\
\hline $\begin{array}{l}\text { Eloctronic Equipment \& } \\
\text { Moesuring Equipmont }\end{array}$ & 36,38 & $.025 \quad(.092)$ \\
\hline Transportation Equipment & 37 & $-.033 \quad(.107)$ \\
\hline Reilroeds & 4011 & $.279 \quad(.123)$ \\
\hline Trucking & 4213,4210 & $-.046 \quad(.081)$ \\
\hline Airlines & 4511,4512 & $-.224 \quad(.091)$ \\
\hline Gas Pipolinos & 4922,4923 &. $.073 \quad(.254)$ \\
\hline $\begin{array}{l}\text { Unrogulated Trensportation, } \\
\text { Communicetion, ond Utilitios }\end{array}$ & $\begin{array}{c}40-49, \text { oxcl. } 4011,4213 \\
4511-12,4813,4911 \\
4922-24,4931-32\end{array}$ & $.158 \quad(.145)$ \\
\hline Wholesele Trede & 50,51 & $-.107 \quad(.093)$ \\
\hline Rotail Trado & $52-59$ & $-.121 \quad(.119)$ \\
\hline Finencial Sorvices & $60-69$ & $.104 \quad(.290)$ \\
\hline Sorvices 1 & $70-79$ & $.330 \quad(.204)$ \\
\hline Sorvicos 2 & $80-89$ & $.281 \quad(.192)$ \\
\hline
\end{tabular}

Table 3, col. 3 rogrossion. Asymptotic robust stenderd errors in peronthoses. 
Appendix Table A2: Year Fixed Effects

\begin{tabular}{l|cc} 
Dependent Variable: & In(SALARY) & $\begin{array}{c}\text { In (TOTAL } \\
\text { COMPENSATION) }\end{array}$ \\
\hline 1985 & 3.758 & 3.220 \\
& $10.245)$ & $10.349)$ \\
1986 & 3.797 & 3.356 \\
& $10.244)$ & $10.346)$ \\
1987 & 3.783 & 3.361 \\
& $10.250)$ & $10.361)$ \\
1988 & 3.923 & 3.478 \\
& $10.248)$ & $10.358)$ \\
1989 & 3.992 & 3.521 \\
& $10.246)$ & $10.358)$ \\
1990 & 3.966 & 3.568 \\
& $10.248)$ & $10.359)$ \\
\hline
\end{tabular}

Year effects for regressions in columns 3 and 5 of Table 3. Asymptotic robust standard errors in parentheses. 